http://ngtt.journals.ac.za

Matthew, Esau

Anglican Church

\title{
Law and religion in South Africa - an Anglican perspective
}

The development of Canon Law in the Anglican Church in South Africa, the Common Principles of Canon law in the Anglican Communion and the involvement of Anglican Archbishops in the writing of the South African Constitution

The beginning of the $21^{\text {st }}$ Century found the Anglican Communion in a crisis. The crisis came about because the Episcopal Church of the United States had elected an openly 'gay' bishop, Gene Robinson, as one of its Diocesan bishops. Parts of the Church in the US joined parts of the Anglican Church in Nigeria, Uganda and Canada (to mention a few) and protested to one of the 'institutional instruments of unity' also known as 'bonds of affection' in the Communion. The Archbishop of Canterbury, one of the 'bonds of affection' was requested to not invite Gene Robinson to participate in another, 'institutional instrument of unity', namely the Lambeth Conference. "The tensions within the Communion stimulated discussion of the meaning and limits of the bonds of affection leading to exploration of ways which the laws of the churches may contribute to more visible global ecclesial communion in Anglicanism"1

The challenge to the Archbishop of Canterbury at the dawn of the $21^{\text {st }}$ century has a parallel in South Africa in the 1867 . The 1867 challenge came at the start of the pioneering work of the first bishop of Cape Town, Robert Gray. "It arose out of a moment of doctrinal controversy." ${ }^{2}$ John William Colenso, the bishop of Natal, was accused of being "a traitor to the promises made at his ordination and consecration, a rebel against the laws of the English Church, an apostate from the faith of the Church Catholic and from Christianity". The Colenso affair got "the Canadian bishops to petition the then Archbishop of Canterbury, Charles Longley, to call together all the bishops of the Anglican Church throughout the world to discuss this (Colenso doctrinal controversy) and other matters". ${ }^{3}$ This was the first meeting of the bishops of the Communion and the inaugural Lambeth Conference.

The birth of Canon Law in Anglican Church in South Africa came about when Robert Gray - the first bishop of Cape Town set about establishing a church not by law established. And in the process of doing so was confronted by the Colenso doctrinal controversy and the doctrine of Canonical Obedience, in the Long v Bishop of Cape Town matter.

This paper briefly traces the development of Canon Law in the Anglican Church in Southern Africa, and the contributions that the church in South Africa made to the Anglican Communion, thus putting itself in a key position to support Religion and Law in South Africa post 1994..

\section{A SHORT LEgAL HistoricAl BACKGROUND}

The Province of the ACSA was legislatively formed in 1870 at the first Provincial Synod. The Preliminary Resolutions taken at that Provincial Synod states;

That inasmuch as the Dioceses of Cape Town, of Grahamstown, of Maritzburg (embracing the Diocese of Natal), of St. Helen, and of the Orange Free State, which originally were 
comprehended as one Diocese of Cape Town, have been constituted an Ecclesiastical Province, of which Cape Town is the Metropolitan See; such constitution having been determined for them in accordance with the decision of authorities of the English Church, through the intention or the effect of Acts of the Crown, under which the said Diocese was sub-divided, ${ }^{4}$

This resolution continues to set the legal parameters for the new Province of South Africa.

And being further confirmed by the oaths of Canonical obedience taken by the other Bishops of those Diocese to the Bishop of Cape Town as their first Metropolitan, and by express acceptance of these relations by all the aforesaid Dioceses, either in acts of the Synods, or in the action of their Clergy and Laity, as well as by the recognition of such Dioceses as a Province by the Archbishops, Primates and other Bishops of the Anglican Communion: We do therefore claim for this Province the Ecclesiastical status, rights, powers, and relations of a Province of the Anglican Communion ${ }^{5}$

This latter part of the resolution was a response to a number of challenges which Robert Gray as the first Bishop of Cape Town had to face:

Firstly, Gray found that the 'English Church' was a combination of the governor's church and a Diocese of the Church of England. In fact the 'English Church' in Cape Town was an extension of the Diocese of London. However because of the political nature of the Colony the 'English Church' could not function as a part of the English Establishment. What was required was for the 'English Church' to be become a Church "not by Law established". Hence the preamble to the Constitution of the Church states;

Whereas it is expedient that the members of a Church, not by Law established, should, for the purpose of its due government, as well as for the management of its property and the ordering of its affairs, formerly set forth the terms of the compact under which it is associated. ${ }^{6}$

The first challenge to Gray was the need of legal structures according to Canon Law, the church needed a Constitution.

However before Gray could have a church not by "Law established" he had to bring the members of the 'English Church' in the huge Diocese of Cape Town together in a Synod which is the Church's highest decision making body, the body which had to adopt and confirm a Constitution. The second challenge which Gray had to confront was that of Canonical Obedience. Both challenges to Gray are adequately covered in Long v Bishop Gray ${ }^{7}$

Canonical Obedience is the authority which Priests and Deacons receive to minister in a diocese and in turn they owe canonical obedience to the bishop of the diocese. ${ }^{8}$ It was destined for a tough passage in the ACSA, when in January 1857, Gray, set about the creation of;

"an organisation which in law would bind together the isolated and independent congregations and communities which then existed"9

Gray discovered that certain legal judgements made in 1841;

"owing to the novelty of the situation, that there was an imperfect apprehension of the true constitutional position of Colonial Churches, and no doubt those who took part in 
passing these resolutions believed that the Churches of the Colonies were a part of the Church of England as by law established."10

Gray made three unsuccessful attempts;

"in the House of Commons (in London) to secure the passage of a Bill"

which would provide for a;

"general Act of Parliament which might be applicable to all Colonial Churches."

His unsuccessful attempts;

"indicated that only by means of a voluntary association could the whole Church be bound together in a recognised legal organisation."

To remedy the situation, Gray, summoned a Synod first in 1856 and then again in 1861. The Synod discussed Rules and Regulations which would help with the organisation of a local church. The summons to the clergy and laity of the Diocese met with resistance. The 1856 session was not attended by Clergy and Lay delegates of five parishes.

"They protested against the holding of the said Synod on the grounds that it constituted an infraction of the law governing the Church of England."

The protestors claimed that the holding of a Synod for Clergy and Laity was in contradiction of the Canons and Constitution of the Church in England and that it had for its object the separation of the Church of England in South Africa from the Mother Church in England.

The Reverend W. Long, the incumbent at St. Peter's Church, Mowbray, strongly objected to this name change and he made his feelings known to Gray.

"I do not my Lord; belong to any religious body in union and communion with the United Church of England and Ireland in the Diocese of Cape Town. I am a minister of the United Church of England and Ireland in the Diocese of Cape Town, and belong to no other religious body."11

Long took issue with a declaration changing the name of the Anglican Church in South Africa, and said,

"I feel that were I as Minister, to carry out this Act by demanding it of my people, I should be as much to blame for asking them as any of the Laity who should sign it."

In 1861 Gray summoned the second Synod and the five churches and Long refused again to participate. Gray then disciplined Long, and removed him from his benefice. Long sought relief from the Supreme Court in Cape Town and when that failed he applied to the Privy Council in London for protection. The Privy Council found in his favour, and held that the sentence by Gray of suspension and deprivation were not warranted by law. The dispute had appeal to the doctrine of Canonical Obedience 


\section{The Doctrine of Canonical Obedience}

"Anglican churches are not confessional denominations possessing formal and definitive legal statements of their beliefs. Laws are employed simply to point to doctrinal documents, extrinsic to the law, which are accepted by the church as normative in matters of faith"12.

Bishops, priests, deacons and laity are required by the Canons of ACSA to make declarations of Assent as well as Oaths of Obedience as the case may be. The oath of canonical obedience to the Bishop is obedience, "in all things lawful and honest". In Long v Bishop of Cape Town, Justice Watermeyer made the following remarks;

"The origin of the differences which have led to this litigation was a direction by a Bishop to the plaintiff (Long) to give a certain notice, which was disobeyed. Now this presbyter or incumbent is bound to the Bishop in canonical obedience, in all things lawful and honest."13

The judge pointed out that should the notice for the Synod have been an illegal act, Long, would have been justified in refusing to follow the instructions of the Bishop based on its illegality. But this was not the case.

The interpretation of Canonical Obedience by Clergy has been a recurring theme in the life of the ACSA. The matter Diocese of False Bay $v$ C. Felix in the CCMA Cape Town is the latest case. The commissioner found that;

"His (Felix) submissions regarding to be an employee are fraught with his confusion to distinguish the laws of the land with the laws of the church. He maintained that God called him to the church to His fulltime ministry within the shelter of the church and that he is subject to Canonical Obedience. ${ }^{14}$

However Felix sought relief from the CCMA despite his own understanding that "he is subject to Canonical Obedience". The Laws of ACSA provide for "Ecclesiastical Tribunals and the Discipline of Ministers of the Church." Canons 36 - 41 "relate to licensed clergy" meaning those who have taken the Oath of Canonical Obedience. Other ministers, meaning; "any person who engages in any public or private ministry in the church, whether formally authorised by ordination or licensing, or elected as a lay official, or formally recognised as having authority or influence over others in the Christian community. It naturally includes bishops, priests deacons, lay officers, all licensed lay ministers, Parish Councillors, Sunday school teachers, side's persons, councillors, music leaders, youth leaders and office holders in church guilds and organisation" enjoy the protection of Ecclesiastical Tribunals.

\section{Canon Law in the Anglican Communion}

In their quest to deal with the crisis which emanated from the consecration of Gene Robinson, the Primates (Archbishops) of the Anglican Communion met in March 2001 in the USA. The Archbishops were keen to find a way of showing to the world that there was much more which held the Communion together than the response to the consecration of an openly 'gay' bishop. They considered the role of Canon Law in the Communion.

Norman Doe ${ }^{15}$ discussed with the Archbishops three things concerning Canon Law and the Communion; 
1. A "reflection on Anglican experiences of church order and law

2. identify the role which the legal system of each Anglican church plays in the context of the global Anglican Communion - especially how collectively these systems point to unwritten common law of the Anglican Communion

3. some practical ideas about how the law of each church might be developed to enhance global communion." ${ }^{16}$

Doe provides a meaning of Canon Law which is the "title given to the legal system which churches of the catholic and apostolic tradition create to regulate their internal life - their government, ministry, doctrine, liturgy, rites and property." ${ }^{17}$ It has three meanings for Anglicans. In its narrow sense "canon law implies simply the code of canons of an Anglican church. Canon law is one category amongst several bodies of law within a particular church"18 The second meaning gives canon law a wider sense. The particular Anglican church has a "formal collection of several bodies of law" which "embraces all formal laws, and includes the constitution, the code of canons, and other formal legal instruments"19 ${ }^{\prime 1}$ This is the case in ACSA. The third meaning of Canon Law is seen in its widest sense and canon law can be "understood as the entire system of ecclesiastical regulation in a particular Anglican church."20 This shows a range of regulatory experiences: humanly created entities which are used to regulate church life - such as unwritten custom, pastoral regulations or directions of bishops, and even decisions of church tribunals. "These entities may or may not appear in the formal, written law of the church (constitution or canons). But they are used to regulate conduct; they are equivalent to canon law."21

In his concluding remarks to the Primates meeting in March 2001, Doe said; "Acknowledging the existence of the ius commune (Latin for "common law") would make more evident what Anglicans share. A declaration of the principles of Anglican canon law would be rooted in theology and based on the best practice of churches, the Anglican common law, and canonical tradition."22

The Archbishops commissioned the production of the 'Principles of Canon Law common to the Anglican Communion' and in the forward to the publication the Archbishop of Canterbury made the following comment about Canon Law.

"Although lawyers are the victims of almost as many unkind jokes as clergy, the truth
is that law, properly understood, is not an alien imposition on a grumbling public but a
way of securing two things for the common good. The first is consistency: law promises
that we shall be treated with equity, not according to someone's arbitrary feelings or
according to our own individual status and power. It gives to all of us the assurance that
we can be heard. The second is clarity about responsibility: we need ways of knowing
who is supposed to do this or that and who is entitled to do this or that, so that we can
act economically and purposefully, instead of being frustrated by a chaotic variety of
expectations and recriminations."23

Archbishop Rowan Williams recognised the protection of the membership of the body of Christ, when he said;

"Canon Law begins from that basic affirmation of equity which is the fact of membership in the Body of Christ $^{24}$ - a status deeper and stronger than any civil contract or philosophical argument. And it seeks clarity about who may do what and who is

- 68 - NGTT Deel 54 Supplementum 4, 2013 
answerable to whom, because every Christian has to know how to work out their responsibility to God within the context of the various relationships and obligations they are involved in. Understanding and knowing how to work with Canon Law is a necessary aspect of exercising authority and holding responsibility in the Church;"25

\section{Principles of Commonality in the Anglican Communion}

Principles of Canon Law which are common in the Anglican Communion, the work of Anglican Communion Legal Advisors, who met in Canterbury in March 2002. They produced a report based on "six conclusions:

1. There are principals of canon law common to the churches of the Anglican Communion;

2. Their existence can be factually established;

3. Each province or church contributes through its own legal system to the principles of canon law common within the Communion;

4. These principles have strong persuasive authority and are fundamental to the selfunderstanding of each of the member churches;

5. These principles have a living force, and contain within themselves the possibility for further development; and

6. The existence of the principles both demonstrates and promotes unity in the Communion." 26

When the Primates met for their meeting in April 2002 the report on the Legal Advisors Consultation was discussed. The Archbishops passed a resolution which "recognised the unwritten law common to the Churches of the Communion and expressed as shared principles of canon law may be understood to constitute a fifth "instrument of unity"27 They further endorsed the suggestion to establish a network of lawyers to work on draft statement and the eventual final statement of principles of commonality. The ACSA was well represented at the Legal Advisors Consultation as well as at the meetings of the Archbishops. At the Primates' meetings ACSAs Archbishop Ndungane was a key participant.

The published final statement have 100 Principles are divided into eight parts or sections.

Part I deals with Nine Principles of Church Order, 'Law in ecclesial society, Law as servant, limits of Law, sources and forms of Law, the rule of Law, the requirement of authority, applicability of Law, interpretation of Law and Juridical presumptions.

"In this section, the Principles are introduced by reference to their wider context, considering the nature of, and necessity for, law in a world made by a God who has embedded concepts of justice in His creation, and who has made Himself known in His Son Jesus Christ." ${ }^{28}$

The second part deals with the Anglican Communion, fellowship of the Communion, instruments of Communion, Autonomy and interdependence, Mutual respect and hospitality.

Ecclesiastical Government is found in Part III with Principles 15 to 24. This section covers Ecclesiastical polity: Leadership and authority: Administration: Representative government: 
Legislative competence and subsidiarity: The diocese and diocesan legislation: The parish and parochial administration: Lay participation in government: Visitation and Due judicial process.

"The(se) Principles confirm that the exercise of ecclesiastical governance is to be characterised by Christian virtues, transparency and the rule of law, which is to be applied with justice and equity within the institutions of a church and by those persons exercising authority. (It) include accountability, appropriate representation, legislative authority, natural justice, due process and the appropriate participation of each of the orders of bishops, clergy and laity." 29

The section that deal with Ministry looks at the role of the Laity, the Ecclesiastical office, the threefold ordained ministry, Diocesan episcopal ministry and the termination of clerical ministry. Part IV is the largest in that;

"In spite the diversity in culture and language in different parts in the Communion, there is a shared commitment of clergy and laity alike, to support public and individual ministry, through ordained officials and lay members, the threefold ordained ministry of bishops, priests and deacons, and archiepiscopal and metropolitical authority. There are underlying principles of pastoral care, issues of professional and personal relationships, issues of confidentiality, and above all, recognition that all who minister should do so "with respect and compassion". ${ }^{30}$

In Part V we find Doctrine and Liturgy. The section starts with the presentation of doctrine followed by the sources of doctrine: development of doctrinal formularies: Preaching, teaching and outreach: Legitimate theological diversity: Doctrinal discipline: Liturgy and public worship: Liturgical revision: forms of service: Liturgical administration: provision of public worship: Liturgical choice: alternative forms of service: Responsible public worship and Liturgical discipline.

"In the Anglican tradition, neither doctrine nor liturgy is "free-floating". Each is bound by authority, doctrine being derived from Scripture and affirmed by the Catholic creeds and historic Anglican formularies; and liturgy has Scripture and the historic deposit of the Book of Common Prayer 1662 as its touchstones." 31

Ecclesiastical Rites such as Baptism; Baptismal discipline; Confirmation; Holy Communion: admission and exclusion; Marriage its nature, purposes and responsibilities; requirements for ecclesiastical marriage and the nullity of marriage; Confession and absolution: The seal of the confessional: Deliverance or exorcism: Death and burial rites are covered in Part VI.

"From the lawyer's point of view, marriage law presents a particularly interesting study in the overlap between church law and the law of the state. The interplay between the exercise of civil legal rights in relation to divorce and remarriage, and the teaching of the churches, has resulted in the development of very diverse approaches to these issues within the churches of the Anglican Communion ${ }^{32}$.

Church property addresses a wide variety of issues relating to the ownership, use, and care of church property, real and personal, by ecclesiastical authorities at all levels of a church. The recurrent theme is the church's interest in ensuring that property be set aside, used, and maintained with reverence and integrity to further the mission of the church. ${ }^{33}$ 
The last part of the 'Common Principles of Canon Law' deals with Ecumenical Relations certainly an age old tradition in Anglicanism.

"Anglican commitment to ecumenism was first articulated by the 1888 Lambeth Conference (Resolution 11). "The Anglican Communion has never seen itself as a complete and self-sufficient entity, but as an expression of Communion within the One Holy Catholic and Apostolic Church which takes seriously its vocation to reach out beyond its own life to the greater unity of the Church." ${ }^{14}$

A glance at the Canons and Constitution of the ACSA will provide a view of most if not all of the Common Principles of Canon Law, it is however the principles relating to ecumenical relations which have assisted succeeding Archbishops of Cape Town to play a role with the religious community in South Africa, from the dark days of apartheid to the Constitutional democratic state which is current in the country. Later Archbishops became involved in interfaith work and were prominent in the World Conference of Religion and Peace worldwide as well as in the South African Chapter of WCRP.

It was at a National Inter - Faith Conference arranged by the WCRP-SA in 1992 where a "Declaration on Religious Rights and Responsibilities" 35 was adopted, which many believe was the for-runner of Section 15, Freedom of religion, belief and opinion; the Commission for the Promotion and Protection of the Rights of Culture, Religious and Linguistic Communities, Section 184; and section 234, Charters of Rights, in the Constitution of the Republic of South Africa, 1996. In fact the WCRP-SA claims that the declaration was one of the documents consulted during the constitution writing process.

Those who signed and subscribed to the declaration described their understanding of a religious community "to mean a group of people who follow a particular system of belief, morality and worship, either in recognition of a divine being, or in the pursuit of spiritual development, or in expression of a sense of belonging through social custom and ritual". They further recognised "that the people of our continent, Africa, belong to diverse religious communities; and regret that in South Africa, religion has sometimes been used to justify injustice, sow conflict and contribute to the oppression, exploitation and suffering of people." ${ }^{\prime 36}$

"The courageous role played by many members of religious communities" was acknowledged. These were praised for "upholding human dignity, justice and peace in the face of repression and division", and the signatories were convinced of the role that the religious communities could play in "redressing past injustice and the construction of a just society." 37

The declaration then affirmed that;

- People shall enjoy freedom of conscience

- $\quad$ Religious communities shall be equal before the law

- $\quad$ Religious communities have moral responsibilities to society

- People have the right to religious education

- People in state institutions shall enjoy religious rights

- $\quad$ Religions have the right to propagate their teachings 
- $\quad$ Religious communities shall have access to the public media

- The state shall recognise systems of family and customary law

- The holy days of religious communities shall be respected

- $\quad$ Religious institutions may own property and be exempt from taxes. ${ }^{38}$

The Interfaith Conference of 1992 committed themselves to the implementation of the declaration and appealed to all religious communities to promote the principles, "convinced that there is an urgent need for all religious communities and the state to accept and implement the principles of (their) declaration; trusting that this will contribute to better relations between the state and religious communities and between religious communities themselves; recognising that these principles will function within the framework of the Bill of Rights.

The values and principles enshrined in the Constitution of South Africa is evidence of the role that religious leaders and particularly Anglican leaders played in the writing of the Constitution of the country. This is in no small part due to their involvement with the development and experience gained over time in Canon Law in the ACSA and in their involvement with the Archbishop of Canterbury, the Primates Meeting, the Lambeth Conference, the Anglican Consultative Councils and with the fifth' instrument of unity' the principles of Canon Law common to the Anglican Communion.

\section{(Endnotes)}

1 Doe, N, 'The Contribution of Common Principles of Canon Law to Ecclesial Communion in Anglicanism' (2008) 10 Ecc LJ 71-91

2 Hill, M Authority in the Church of England in Conn, J. Doe, N. Fox, J INITIATION, MEMBERSHIP AND AUTHORITY IN ANGLICAN AND ROMAN CATHOLIC CANON LAW, The Centre for Law and Religion Cardiff University, Pontifical Gregorian University and Pontifical University of St. Thomas Aquinas, 2005

3 Ibid p 264

4 Constitution and Canons of the Anglican Church of Southern Africa, ACSA, Publishing Committee, 2011

5 ibid

6 ibid

7 Day, Hermitage, E. The Legal Development of the Church of the Province of South Africa 1934- 1936, English Church Bookshop, Cape Town.

8 Hill, M Authority in the Church of England 2005 p 271

9 ibid

10 ibid

11 Court Record, Long v Bishop of Cape Town, 1862:1xxv

12 Doe, N. 1998:197

13 Day, Hermitage, E. The Legal Development of the Church of the Province of South Africa 1934- 1936, English Church Bookshop, Cape Town.

14 Brummer, C. Felix v Diocese of False Bay, IN LIMINE RULING, WE 61251, 9 September 2011

15 Professor Doe is a professor at the Law School of Cardiff University, Wales and Director of its Centre for Law and Religion.

16 Norman Doe. Canon Law and Communion. Address to the Primates meeting Kanuga Episcopal Center, USA March 8, 2001 p 1

17 ibid 
18 ibid

19 ibid

20 ibid

$21 \mathrm{ibid}$

22 ibid

23 The Principles of Canon Law common to the Churches in the Anglican Communion 2008

24 My emphasis

25 ibid

26 Doe, N, 'The Contribution of Common Principles of Canon Law to Ecclesial Communion in

Anglicanism' (2008) 10 Ecc LJ 73

27 ibid

28 ibid

29 ibid

30 ibid

$31 \mathrm{ibid}$

32 ibid

33 ibid

34 ibid

35 www.wcrsa.org.za accessed October 2011

36 ibid

$37 \mathrm{ibid}$

$38 \mathrm{ibid}$

\section{BiBLIOGRAPHY}

Conn, J. Doe, N. Fox, J INITIATION,MEMBERSHIP AND AUTHORITY IN ANGLICAN AND ROMAN CATHOLIC CANON LAW, The Centre for Law and Religion Cardiff University, Pontifical Gregorian University and Pontifical University of St. Thomas Aquinas, 2005

Day, Hermitage, E. THE LEGAL DEVELOPMENT OF THE CHURCH OF THE PROVINCE OF SOUTH AFRICA 19341936, English Church Bookshop, Cape Town.

Doe, N, THE CONTRIBUTION OF COMMON PRINCIPLES OF CANON LAW TO ECCLESIAL COMMUNION IN ANGLICANISM (2008) 10 ECC LJ 71-91

Doe. CANON LAW AND COMMUNION. Address to the Primates meeting Kanuga Episcopal Center, USA March 8, 2001

Clarke, B. ANGLICANS AGAINST APARTHEID, Cluster Publications, Pietermaritzberg, RSA 2008

Hill, M. ECCLESIASTICAL LAW SECOND EDITION, Oxford University Press,

Oxford, UK, 2001

Suggit, J. \& Goedhals, M. CHANGE AND CHALLENGE CPSA, Marshalltown, RSA, 1998

Worsnip, M.E. BETWEEN TWO FIRES - THE ANGLICAN CHURCH AND APARTHEID, University of Natal Press, Pietermaritzburg, RSA 1991 